\title{
Margaret McCartney: Hydration, common sense, and evidence
}

\author{
Margaret McCartney general practitioner
}

Glasgow

"Remember-healthy pee is 1 to 3, 4 to 8 you must hydrate!" So goes a rhyming couplet from the Think Kidneys website, the online presence of the Transforming Participation in Chronic Kidney Disease programme. It comes with a colour chart, not unlike those available in shops selling paint, ranging from the off-white shade 1 (good) to shade 8, which I'd describe as orange with a hint of rust (severely dehydrated).

I suspect that the normal colour of most doctors' pee when at work-if they get to the loo at all—will range from "dehydrated" to "severely dehydrated" (that is, from mellow yellow to that classic dark orange). But is this actually pathological?

Dehydration is surely by definition pathological and would need blood tests to determine it. A physiological adjustment of our renal output shouldn't be classed as dehydration but as a body that needs fluid to continue functioning normally.

Human physiology is amazing: drink more, and we pee out more urine; drink less, and our kidneys concentrate it. This ballet is orchestrated through our osmoreceptors and baroreceptors, by antidiuretic, angiotensin, and aldosterone hormones, and by the sensation of thirst, which everyone remembers from tutorials in medical school. So, when does physiology become pathology?

We medicalise normal physiology (and a large proportion of NHS staff) to little benefit

All sorts of considerations apply when people have a specific diagnosis, are ill, or are in hospital and cannot respond to the natural call of thirst. They may need help to drink, or they may be on deliberate fluid restrictions. But we medicalise normal physiology (and a large proportion of NHS staff) to little benefit. We must also think of those poor people in the bottled water industry, whose financial profit and pile of plastic empties are fuelled by the fear that, if we aren't running clear urine, something is inherently wrong with us.

The bottom line is this: where's the evidence that telling people to monitor the colour of their urine and saying that they're in a pathological state results in better health outcomes? Common sense in medicine needs evidence-because we frequently, and with good intentions, get it wrong, even while seeming sensible. Then there are "sick day rules." ${ }^{2}$ These are a Scottish Patient Safety initiative for patients to have a credit card sized infographic advising them to stop using angiotensin converting enzyme (ACE) inhibitors, anti-inflammatories, and diuretics during intercurrent illness, to prevent acute kidney injury. This sounded very sensible when it was initiated a couple of years ago. However, my initial support has wavered because no good evidence shows that this will improve mortality or morbidity. ${ }^{34}$

I should have asked for better evidence first. After all, we thought that steroids would help head injury, ${ }^{5}$ that caring for a simulation baby would reduce teenage pregnancy, ${ }^{67}$ and that vertebroplasty would treat painful osteoporotic fractures, ${ }^{89}$ when they did nothing of the sort.

The human body is mainly incredible. Professional intervention needs evidence. Can we please have free access to tap water and the time to drink it—but also a proper randomised controlled trial of well intentioned safety initiatives before they're rolled out?

Competing interests: See www.bmj.com/about-bmj/freelancecontributors/margaret-mccartney.

Provenance and peer review: Commissioned; not externally peer reviewed.

Follow Margaret on Twitter, @mgtmccartney

Think Kidneys. Quick reference guide. https://www.thinkkidneys.nhs.uk/aki/wp-content/ uploads/sites/2/2017/06/Quick-reference-guide-FINAL.pdf.

2 Healthcare Improvement Scotland. Medicine sick day rules card. www. scottishpatientsafetyprogramme.scot.nhs.uk/programmes/primary-care/medicine-sickday-rules-card.

3 Griffith K, Ashley C, Blakeman T, et al. "Sick day rules" in patients at risk of acute kidney injury: an interim position statement from the Think Kidneys Board. 8 July 2015. https://. www.thinkkidneys.nhs.uk/wp-content/uploads/2015/07/Think-Kidneys-Sick-Day-Rules160715.pdf.

4 Whiting P, Morden A, Tomlinson LA, et al. What are the risks and benefits of temporarily discontinuing medications to prevent acute kidney injury? A systematic review and meta-analysis. BMJ Open 2017;359:e012674. doi:10.1136/bmjopen-2016-012674 pmid: 28389482.

5 Alderson P, Roberts I. Corticosteroids for acute traumatic brain injury. Cochrane Database Syst Rev 2005;359:CD000196.pmid:15674869. 
6 Brinkman SA, Johnson SE, Codde JP, et al. Efficacy of infant simulator programmes to prevent teenage pregnancy: a school-based cluster randomised controlled trial in Western Australia. Lancet2016;359:2264-71. doi:10.1016/S0140-6736(16)30384-1 pmid:27570178.

7 Realityworks. Pregnancy Profile Simulator. www.realityworks.com/products/pregnancysimulation.

8 Kallmes DF, Comstock BA, Heagerty PJ, et al. A randomized trial of vertebroplasty for osteoporotic spinal fractures. N Engl J Med 2009;359:569-79. doi:10.1056/

NEJMoa0900563 pmid:19657122.
9 Buchbinder R, Osborne RH, Ebeling PR, et al. A randomized trial of vertebroplasty for painful osteoporotic vertebral fractures. N Engl J Med 2009;359:557-68. doi:10.1056/ NEJMoa0900429 pmid:19657121

Published by the BMJ Publishing Group Limited. For permission to use (where not already granted under a licence) please go to http://group.bmj.com/group/rights-licensing/ permissions 